\title{
Modeling and Performance Analysis of Simplified Two-Diode Model of Photovoltaic Cells
}

\author{
Saripalli Bhanu Prakash*, Gagan Singh and Sonika Singh \\ Department of Electrical and Electronics \& Communication Engineering, DIT University, Dehradun, India
}

For a quick and consistent photovoltaic (PV) module design, an effective, fast, and exact simulator is crucial to examine the performance of the photovoltaic cell under partial or quick variation of temperature and irradiance. The most prevalent modeling strategy is to apply an equivalent (electrical) circuit that encompasses together non-linear and linear mechanisms. This work proposes the modeling and analysis for a four-parameter two-diode photovoltaic cell model based on the manufacturer's data-sheet. The proposed model needs only four parameters compared to the previously developed seven-parameter two-diode model to reduce the computational complexity. To develop a specific model of photovoltaic cells, the fundamental requirement is the data of temperature and irradiance. The variation of these variables totally affects the output

OPEN ACCESS

Edited by:

Carlos Marques,

University of Aveiro, Portugal

Reviewed by:

Rahul Kumar Gangwar,

Peking University, China

Dharmendra Kumar,

Madan Mohan Malaviya University of

Technology, India

${ }^{*}$ Correspondence:

Saripalli Bhanu Prakash sb.prakash@dituniversity.edu.in

Specialty section: This article was submitted to Optics and Photonics,

a section of the journal

Frontiers in Physics

Received: 03 April 2021

Accepted: 15 April 2021

Published: 25 October 2021

Citation:

Prakash SB, Singh G and Singh S (2021) Modeling and Performance

Analysis of Simplified Two-Diode Model of Photovoltaic Cells.

Front. Phys. 9:690588

doi: 10.3389/fphy.2021.690588 constraints like current, voltage, and power. Thus, it is substantial to design a precise model of the photovoltaic cell module with a reduced computation period. The two-diode photovoltaic module with four constraints is identified to be more accurate and have improved performance compared to a one-diode model particularly at lower irradiance. To confirm the accuracy of the proposed model the method is applied on two different photovoltaic modules. The proposed model and modeling method are helpful for power electronic designers who require a fast, accurate, simple, and easy to implement method for use in photovoltaic system simulation. The electrical equivalent circuit and standard equations of photovoltaic cells are analyzed and the proposed two-diode model is simulated using MATLAB/Simulink software and validated for poly-crystalline and mono-crystalline solar cells under standard test conditions.

Keywords: one-diode photovoltaic model, two-diode photovoltaic model, poly-crystalline solar cell, circuit constraints, mono-crystalline solar cell

\section{INTRODUCTION}

In recent years, several models have been developed including the single-diode $\mathrm{R}_{\mathrm{S}}$ model, $\mathrm{R}_{\mathrm{P}}$ model, and double-diode and triple-diode model [1-3]. The most modest scheme is a one-diode PV model (ideal case) as it involves only three variables: current at short circuit, voltage at open circuit, and diode ideality factor. The enhanced type of the model includes the insertion of series resistance $\mathrm{R}_{\mathrm{s}}$ to the equivalent circuit [4]. While this model suffers from inconsistencies with the change in the temperature values as it does not considered the voltage temperature coefficient. The upgraded version is the $\mathrm{R}_{\mathrm{P}}$ model by the insertion of a shunt resistor to the equivalent circuit [5]. Though this model has improved accuracy, with the insertion of $\mathrm{R}_{\mathrm{P}}$ the computational parameters are increased to five which leads to more computation time. 


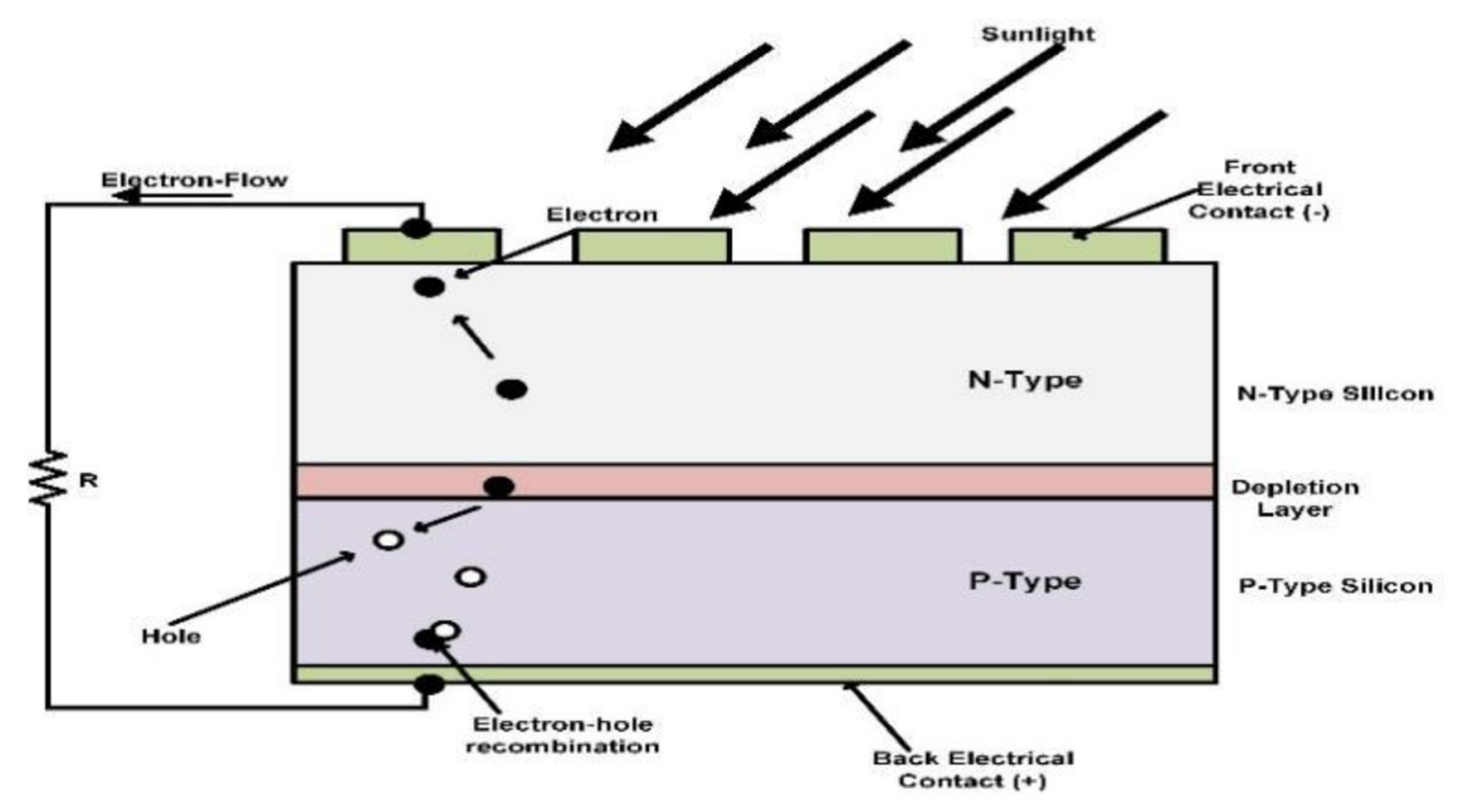

FIGURE 1 | Structure of a photovoltaic cell [9].

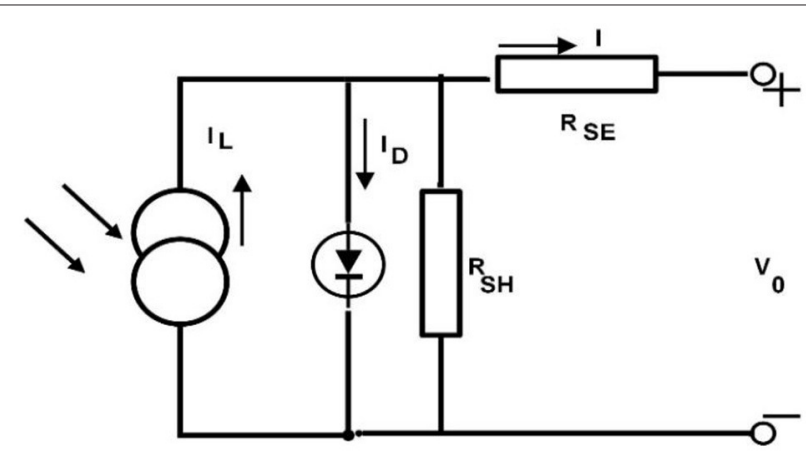

FIGURE 2 | Equivalent circuit model: one-diode photovoltaic (PV) model [3].

In general, most of the constructors only provide data about constraints like voltage at open circuit $\left(\mathrm{V}_{\mathrm{o}}\right)$, current at short circuit $\left(\mathrm{I}_{\mathrm{SC}}\right)$, peak or maximum power $\left(P_{m p p}\right)$, current at $P_{m p p}\left(I_{m p p}\right)$, and voltage at $P_{m p p}\left(V_{m p p}\right)$ at standard operating conditions and inappropriately these data are far away from what is essential for modeling because a PV cell is used to functioning at various ecological conditions. The non-linear performance of current-voltage characteristics requires the alteration of constraints by using the manufacturer data sheet $[6,7]$.

So far, many researchers have developed a single-diode model by making an assumption that nonappearance of recombination loss occurs in the depletion layer. In reality, it is not possible to satisfactorily model by using a single diode. Consideration of this loss results in a more exact model, identified as the two-diode model [8]. But, with the insertion of the extra diode it increases the constraints to seven and the new constraints include reverse saturation current $I_{D S 2}$ and ideality factor $C_{2}$ of the second diode. The main task is now to evaluate the values of the model constraints while keeping a realistic computational energy. The key knowledge of this paper, to develop a detailed model of a two-diode PV cell module, is by simplifying the current equation and thereby reducing the constraints to four. The precision of this PV model is confirmed by two different solar PV cells from the constructor information sheet and behavior performance is compared with a one-diode $R_{S H}$ model. This enhanced model can be useful for researchers who work on the precise modeling of photovoltaic (PV) modules.

\section{FUNDAMENTALS AND CIRCUIT MODEL OF PHOTOVOLTAIC CELLS}

\section{Effective Principle of Photovoltaic Cells}

A basic structure of a typical photovoltaic cell is represented in Figure 1. A photovoltaic cell essentially consists of two films doped in a different way and behaves as a semiconductor diode through its p-n junction, which is exposed to incident light [9]. When the photovoltaic cell is exposed to this light, electron-hole pairs are generated which initiates the flow of the electric current if the circuit is closed from cathode ( $\mathrm{N}$ type) to anode (P type).

By this convention, the electric current direction is always chosen with reference to the direction of movement of positive charges. Consequently, the direction of current in the load circuit is shown from a positive to negative terminal.

\section{Electrical Equivalent Circuit of One-Diode Photovoltaic Cell Model}

The one-diode model with a series and parallel resistor is represented in Figure 2 [3]. For practical reasons, we cannot 


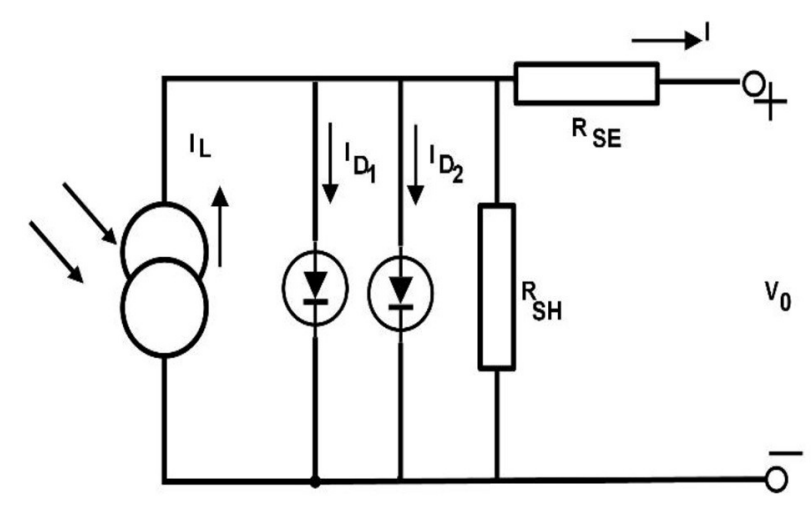

FIGURE 3 | Equivalent circuit model: two-diode photovoltaic (PV) model [2].

neglect the $\mathrm{R}_{\mathrm{SE}}$ and $\mathrm{R}_{\mathrm{SH}}$ resistor in photovoltaic cell modeling. With the addition of these resistors, the constraints are now increased to five which also lengthens the computation time. This model is the most popular due its ease, accuracy, and easy of implementation. Despite of its advantages, the model's accuracy will worsen at lower irradiance [10].

\section{MODELING OF A PHOTOVOLTAIC CELL AND DETERMINATION OF CONSTRAINTS}

\section{Modeling of a Two-Diode Photovoltaic Cell}

The two-diode PV model is represented in Figure 3 [2]. Obviously, two more new constraints now need to be considered: the reverse saturation diode current $\mathrm{I}_{\mathrm{DS} 2}$ and ideality factor $\mathrm{C}_{2}$. The current $\mathrm{I}_{\mathrm{DS} 2}$ compensates for the consequence of recombination loss in the depletion area [11].

By applying KVL to Figure 3, we get the expression for current I:

$$
\begin{array}{r}
I=I_{L}-I_{D 1}-I_{D 2}-I_{S H} \\
I=I_{L}-I_{D 1}-I_{D 2} \frac{V_{0}+I R_{S E}}{R_{S H}}
\end{array}
$$

$I_{L}$ is the light or photo current, $I_{D 1}$ and $I_{D 2}$ is the current through diode 1 and diode $2, I_{S H}$ is the current through the shunt resistor $=\frac{V_{0}+I R_{S E}}{R_{S H}}, R_{S E}$ and $R_{S H}$ are series and shunt resistances, $V_{0}$ is applied voltage across diode, and $I$ is module output current [12].

Currents through diodes 1 and 2 are given by

$$
\begin{aligned}
& I_{D 1}=I_{D s 1}\left[\left(e^{\frac{V_{o}+I R_{S E}}{C_{1} V_{T} N_{S E}}}\right)-1\right] \\
& I_{D 2}=I_{D s 2}\left[\left(e^{\frac{V_{o}+I R_{S E}}{C_{2} V_{T} N_{S E}}}\right)-1\right] \\
& I=I_{L}-I_{D s 1}\left[\left(e^{\frac{V_{o}+I R_{S E}}{C_{1} V_{T} N_{S E}}}\right)-1\right] \\
& -I_{D s 2}\left[\left(e^{\frac{V_{o}+I R_{S E}}{C_{2} V_{T} N_{S E}}}\right)-1\right]-\frac{V_{0}+I R_{S E}}{R_{S H}}
\end{aligned}
$$

$I_{D s 1}$ and $I_{D s 2}$ are reverse saturation diode current, $C_{1}$ and $C_{2}$ are the diode ideality factor of 1 and $2, N_{S E}$ is series-connected $\mathrm{PV}$ cells, $V_{T}$ is thermal voltage $=\frac{K T_{A c}}{q}, V_{T}$ is approximately
$25.856 \mathrm{mV}$ at 300 Kelvin, $q$ is $\left(1.602 X 10^{-19}\right)$, $\mathrm{C}$ is electron charge, $K-\left(1.38 \times 10^{-23}\right) \frac{\text { Joule }}{\text { Kelvin }}$ is a Boltzmann constant, and $T_{A c}$ is the cell's absolute temperature in Kelvin.

Light or photo current [9] is given by

$$
I_{L}=\left(I_{S C}+\gamma_{S C} \Delta T_{A c}\right) \frac{G_{i r}}{G_{S C}}
$$

$G_{i r}$ - irradiance in $\frac{W}{m^{2}}, G_{S C}$ - irradiance at the standard test condition $(\mathrm{STC})=1,000 \frac{\mathrm{W}}{\mathrm{m}^{2}}, T_{A c}=T_{A c}-\Delta T_{A c, \text { ref }}$ (Kelvin), $T_{A c \text {,ref }}-(25+273=298$ Kelvin $), I_{S C}$ is the cell's short circuit current at $\mathrm{STC}\left(25^{\circ}\right)$, and $\gamma_{S C}$ is the current temperature coefficient $(\mathrm{A} / \mathrm{K})$.

$$
I_{D S}=I_{D S 1}=I_{D S 2}=\frac{I_{S C}+\gamma_{S C} \Delta T_{A c}}{\left(e^{\frac{V_{0}+\gamma_{V} \Delta T_{A c}}{V_{\Delta T}\left[\frac{C_{1}+C_{2}}{P}\right]}}-1\right)}
$$

where $\gamma_{V}$ - voltage temperature coefficient $(\mathrm{V} / \mathrm{K})$.

In making the model simple for analysis, the seven constraints are reduced to four by assuming the $I_{D S}=I_{D S 1}=I_{D S 2}$ and $\left.\frac{\left(C_{1}+C_{2}\right.}{p}\right)=1$ as described in [12] Therefore.

$$
I_{D S}=I_{D S 1}=I_{D S 2}=\frac{I_{S C}+\gamma_{S C} \Delta T_{A c}}{\left(e^{\frac{V_{0}+\gamma_{V} \Delta T_{A c}}{V_{\Delta T}}}-1\right)}
$$

\section{Determination of Photovoltaic Module Constraints}

Owing to its complication in analysis and constraints estimation, the analysis and simulation of the PV cell in the two-diode model is not so simple. To make it easier to study the following assumptions are considered: the $I_{D S}=I_{D S 1}=I_{D S 2}$ and $\left.\frac{\left(C_{1}+C_{2}\right.}{p}\right)=1$. By inputting the temperature and irradiance in Equations (3) and (5), the light current and diode saturation currents are estimated by using the constructor datasheet. By setting the values of ideality factors $C_{1}=1$ and $C_{2}=1.2$ yields the best suitable outcomes in the current-voltage curve of the PV cell module. These alterations make the two-diode model into its simplified form and therefore attractive for PV system simulation. In general, the constructor gives data of current at short circuit $\left(I_{S C}\right)$, voltage at open circuit $\left(V_{o}\right)$ and peak or maximum power $\left(P_{m p p}\right)$. Now we will evaluate the current equation shown below for three conditions: current $\left(I_{S C}\right)$ at short circuit, voltage $\left(V_{o}\right)$ at open circuit, and peak or maximum power $\left(P_{m p p}\right)$ point condition.

$$
I=I_{L}-I_{D 1}-I_{D 2}-\frac{V_{0}+I R_{S E}}{R_{S H}}
$$

At the short circuit condition

$$
\begin{array}{r}
I=I_{S C, S T C} ; V_{0}=0 \\
I_{S C, S T C}=I_{L, S T C}-I_{D 1, S T C}-I_{D 2, S T C}-\frac{I_{S C, S T C} R_{S E}}{R_{S H}}
\end{array}
$$

where, $I_{D 1, S T C}=I_{D s 1, S T C}\left[\left(e^{\frac{I_{S C, S T C} R_{S E}}{C_{1} V_{T} N_{S E}}}\right)-1\right]$ and $I_{D 2, S T C}=$ $I_{D S 2, S T C}\left[\left(e^{\frac{I_{S C, S T C} R_{S E}}{C_{2} V_{T} N_{S E}}}\right)-1\right]$ 


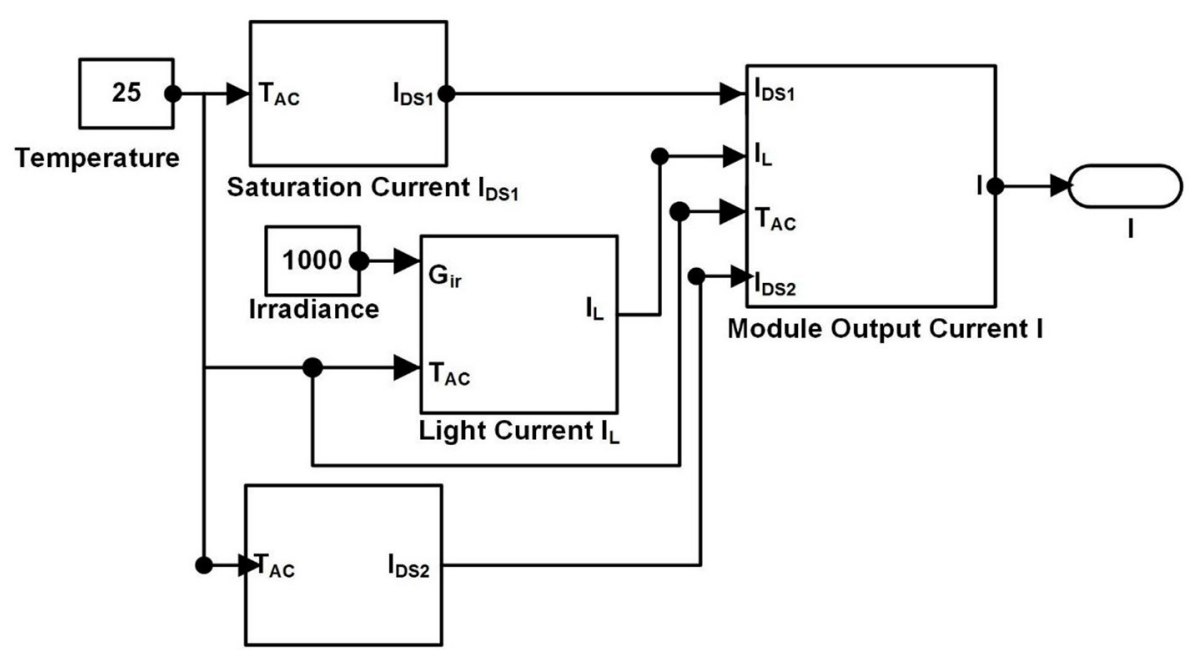

Saturation Current IDS2

FIGURE 4 | Complete sub-system model of proposed two-diode photovoltaic (PV) model.

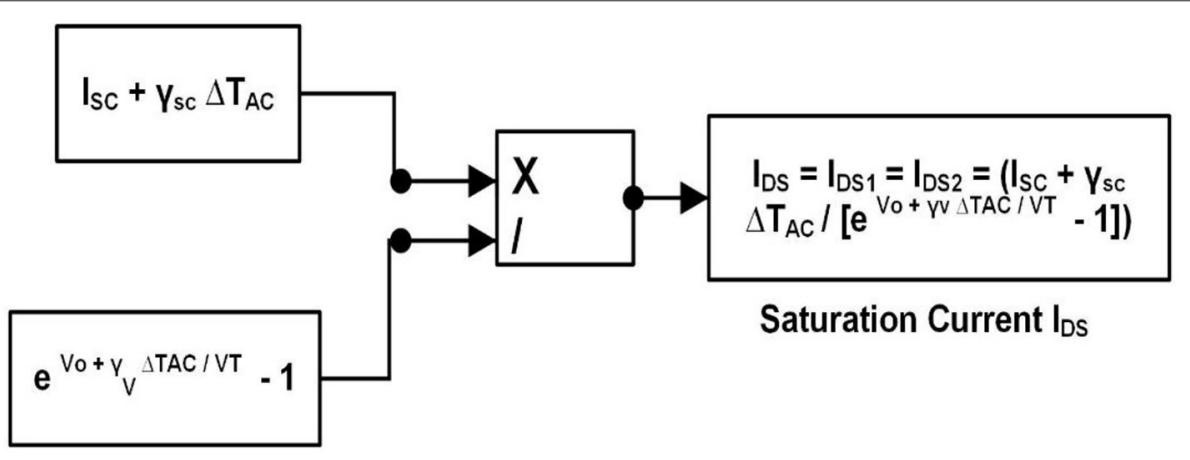

FIGURE 5 | Saturation current (IDS) of proposed two-diode model.

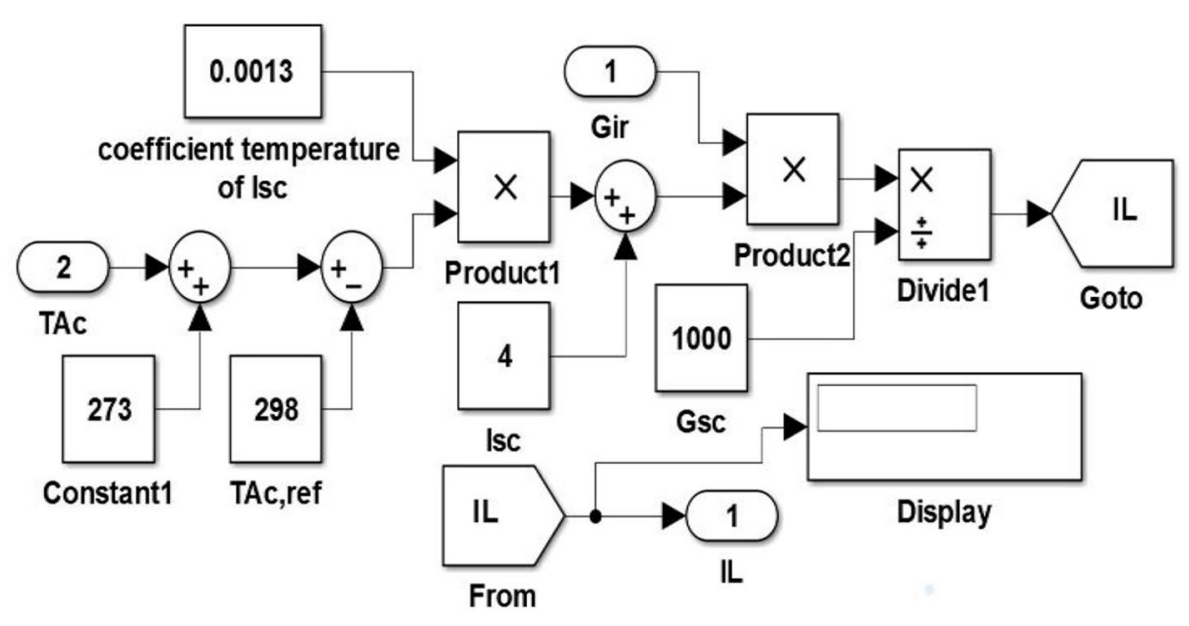

FIGURE 6 | Light current (LL) of proposed two-diode model. 


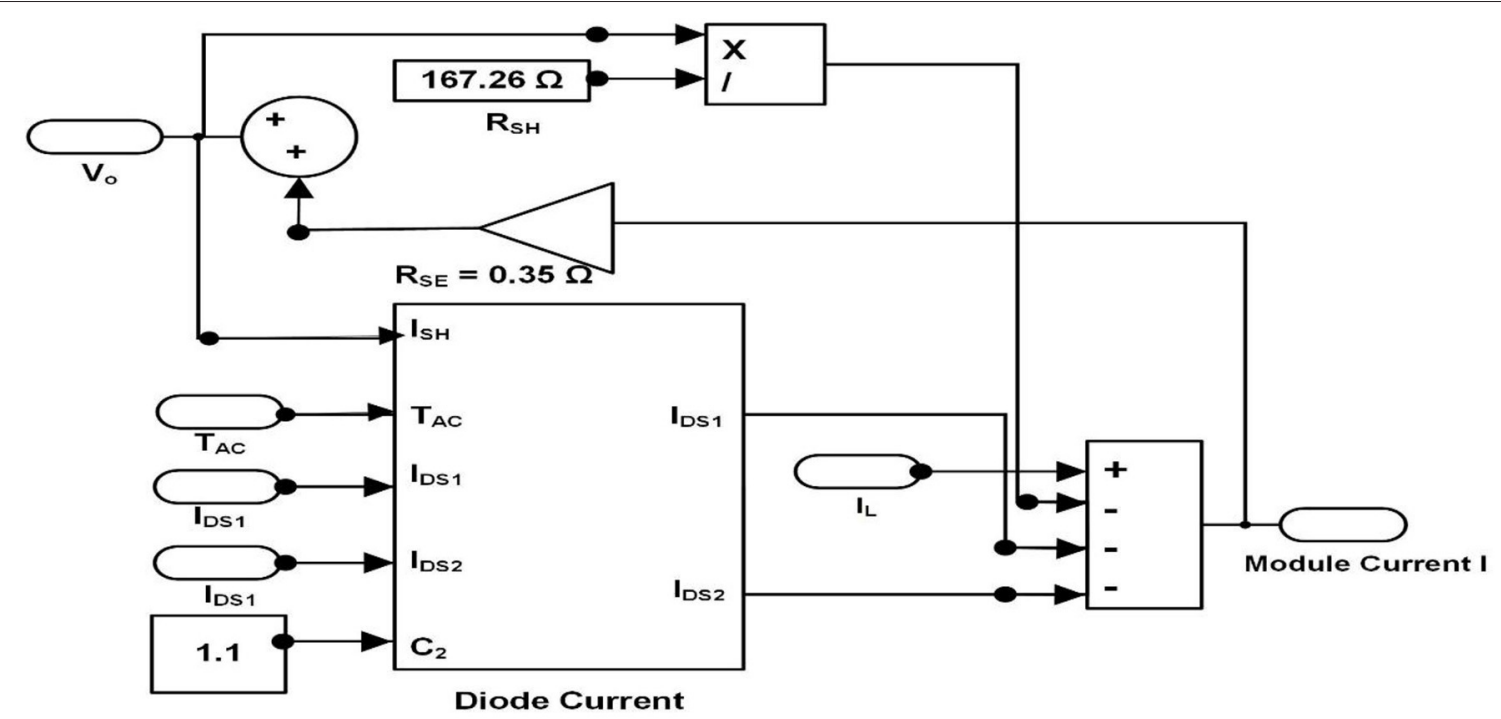

FIGURE 7 | Module output current (I) of proposed two-diode model.

TABLE 1 | Component specifications from constructor data sheet.

\begin{tabular}{lll}
\hline Constraints & $\begin{array}{l}\text { Mono-crystalline } \\
\text { DS-A1-80 solar } \\
\text { panel }\end{array}$ & $\begin{array}{l}\text { Poly-crystalline } \\
\text { Solarex MSX-64 }\end{array}$ \\
\hline Maximum power $\left(P_{m p p}\right)$ & $80 \mathrm{~W}$ & $64 \mathrm{~W}$ \\
Voltage at $P_{\text {mpp }}\left(V_{\text {mpp }}\right)$ & $17.2 \mathrm{~V}$ & $17.5 \mathrm{~V}$ \\
Current at $P_{\text {mpp }}\left(I_{\text {mpp }}\right)$ & $4.66 \mathrm{~A}$ & $3.66 \mathrm{~A}$ \\
Voltage at open circuit $\left(V_{o}\right)$ & $21.3 \mathrm{~V}$ & $21.3 \mathrm{~V}$ \\
Current at short circuit $\left(I_{S C}\right)$ & $5.29 \mathrm{~A}$ & $4 \mathrm{~A}$ \\
Series-connected cell $\left(N_{S E}\right)$ & 36 & 36 \\
Voltage temperature coefficient $\left(\gamma_{\mathrm{V}}\right)$ & $-0.38 \mathrm{~V} /{ }^{\circ} \mathrm{C}$ & $-80 \mathrm{mV} /{ }^{\circ} \mathrm{C}$ \\
Voltage temperature coefficient $\left(\gamma_{S C}\right)$ & $0.13^{\circ} \mathrm{C}$ & $0.65^{\circ} \mathrm{C}$ \\
\hline
\end{tabular}

At the open circuit condition

$$
\begin{array}{r}
I=0 ; V_{0}=V_{o, S T C} \\
0=I_{L, S T C}-I_{D 1, S T C}-I_{D 2, S T C}-\frac{V_{o, S T C}}{R_{S H}}
\end{array}
$$

From Equation (7)

$$
I_{L, S T C}=I_{D 1, S T C}+I_{D 2, S T C}+\frac{V_{o, S T C}}{R_{S H}}
$$

where $I_{D 1, S T C}=I_{D s 1, S T C}\left[\left(e^{\frac{V_{O, S T C}}{C_{1} V_{T} N_{S E}}}\right)-1\right]$ and $I_{D 2, S T C}=$ $I_{D s 2, S T C}\left[\left(e^{\frac{V_{O, S T C}}{C_{2} V_{T} N_{S E}}}\right)-1\right]$

At the maximum power condition

$$
\begin{aligned}
I_{m p p, S T C}= & I_{L, S T C}-I_{D 1, S T C}-I_{D 2, S T C} \\
& -\frac{V_{m p p, S T C}+I_{m p p, S T C} R_{S E}}{R_{S H}}
\end{aligned}
$$

TABLE 2 | Estimated values of proposed two-diode model.

\begin{tabular}{lll}
\hline Constraints & $\begin{array}{l}\text { Mono-crystalline } \\
\text { DS-A1-80 solar } \\
\text { panel }\end{array}$ & $\begin{array}{l}\text { Poly-crystalline } \\
\text { Solarex MSX-64 }\end{array}$ \\
\hline Maximum power $\left(P_{m p p}\right)$ & $80.08 \mathrm{~W}$ & $64.159 \mathrm{~W}$ \\
Voltage at $P_{\text {mpp }}\left(V_{m p p}\right)$ & $17.04 \mathrm{~V}$ & $17.46 \mathrm{~V}$ \\
Current at $P_{\text {mpp }}\left(I_{m p p}\right)$ & $4.69 \mathrm{~A}$ & $3.67 \mathrm{~A}$ \\
Voltage at open circuit $\left(V_{o}\right)$ & $21.3 \mathrm{~V}$ & $21.3 \mathrm{~V}$ \\
Current at short circuit $\left(I_{S C}\right)$ & $5.29 \mathrm{~A}$ & $4 \mathrm{~A}$ \\
Light current $\left(I_{L}\right)$ & $5.29 \mathrm{~A}$ & $4.01 \mathrm{~A}$ \\
Saturation currents $\left(I_{D S 1}=I_{D S 2}\right)$ & $5.207 \times 10^{-10} \mathrm{~A}$ & $3.937 \times 10^{-10} \mathrm{~A}$ \\
Series resistance $\left(R_{S E}\right)$ & $0.34 \Omega$ & $0.3 \Omega$ \\
Shunt resistance $\left(R_{S H}\right)$ & $157.22 \Omega$ & $160.4 \Omega$ \\
\hline
\end{tabular}

TABLE 3 | Estimated values of one-diode $R_{S H}$ model.

\begin{tabular}{lll}
\hline Constraints & $\begin{array}{l}\text { Mono-crystalline } \\
\text { DS-A1-80 solar } \\
\text { panel }\end{array}$ & $\begin{array}{l}\text { Poly-crystalline } \\
\text { Solarex MSX-64 }\end{array}$ \\
\hline Maximum power $\left(P_{\text {mpp }}\right)$ & $80.07 \mathrm{~W}$ & $63.55 \mathrm{~W}$ \\
Voltage at $P_{\text {mpp }}\left(V_{\text {mpp }}\right)$ & $16.61 \mathrm{~V}$ & $17.46 \mathrm{~V}$ \\
Current at $P_{\text {mpp }}\left(I_{\text {mpp }}\right)$ & $4.67 \mathrm{~A}$ & $3.64 \mathrm{~A}$ \\
Voltage at open circuit $\left(V_{o}\right)$ & $21.3 \mathrm{~V}$ & $21.3 \mathrm{~V}$ \\
Current at short circuit $\left(I_{S C}\right)$ & $5.29 \mathrm{~A}$ & $4 \mathrm{~A}$ \\
Light current $\left(I_{L}\right)$ & $5.28 \mathrm{~A}$ & $4.01 \mathrm{~A}$ \\
Saturation currents $\left(I_{D S 1}=I_{D S 2}\right)$ & $2.423 \times 10^{-8} \mathrm{~A}$ & $1.82 \times 10^{-8} \mathrm{~A}$ \\
Diode ideality factor $(C)$ & 1.2 & 1.2 \\
Series resistance $\left(R_{S E}\right)$ & $0.22 \Omega$ & $0.2 \Omega$ \\
Shunt resistance $\left(R_{S H}\right)$ & $282.33 \Omega$ & $310 \Omega$ \\
& &
\end{tabular}


TABLE 4 | Comparison of estimated values at maximum power $\left(P_{m p p}\right)$ of the two-diode model and one-diode $\left(R_{S H}\right)$ model for a mono-crystalline (DS-A1-80) solar cell.

\begin{tabular}{llllll}
\hline Constraints & $\begin{array}{l}\text { Manufacturer } \\
\text { aata at STC }\end{array}$ & $\begin{array}{l}\text { Two-diode } \\
\text { model }\end{array}$ & $\begin{array}{l}\text { One-diode }\left(\mathbf{R}_{\mathbf{S H}}\right) \\
\text { model }\end{array}$ & $\begin{array}{l}\text { \% relative error of } \\
\text { two-diode model }\end{array}$ & $\begin{array}{l}\text { \% relative error of } \\
\text { one-diode model }\end{array}$ \\
\hline Maximum power $\left(P_{\text {mpp }}\right)$ & $80 \mathrm{~W}$ & $80.08 \mathrm{~W}$ & $80.07 \mathrm{~W}$ & 0.099 & 0.087 \\
Voltage at $P_{\text {mpp }}\left(V_{\text {mpp }}\right)$ & $17.2 \mathrm{~V}$ & $17.04 \mathrm{~V}$ & $16.61 \mathrm{~V}$ & 0.938 & 3.552 \\
Current at $P_{\text {mpp }}\left(I_{\text {mpp }}\right)$ & $4.66 \mathrm{~A}$ & $4.69 \mathrm{~A}$ & $4.67 \mathrm{~A}$ & 0.639 & 0.214 \\
Voltage at open circuit $\left(V_{0}\right)$ & $21.3 \mathrm{~V}$ & $21.3 \mathrm{~V}$ & $21.3 \mathrm{~V}$ & 0.00 & 0.00 \\
Current at short circuit $\left(I_{S C}\right)$ & $5.29 \mathrm{~A}$ & $5.29 \mathrm{~A}$ & $5.29 \mathrm{~A}$ & 0.00 & 0.00 \\
\hline
\end{tabular}

TABLE 5 | Comparison of estimated values at maximum power $\left(P_{m p p}\right)$ of the two-diode model and one-diode $\left(R_{S H}\right)$ model for a poly-crystalline solar cell (MSX-64).

\begin{tabular}{llllll}
\hline Constraints & $\begin{array}{l}\text { Manufacturer } \\
\text { data at STC }\end{array}$ & $\begin{array}{l}\text { Two-diode } \\
\text { model }\end{array}$ & $\begin{array}{l}\text { One-diode }\left(\mathbf{R}_{\mathbf{S H}}\right) \\
\text { model }\end{array}$ & $\begin{array}{l}\text { \% relative error of } \\
\text { two-diode model }\end{array}$ & $\begin{array}{l}\text { \% relative error of } \\
\text { one-diode model }\end{array}$ \\
\hline Maximum power $\left(P_{\text {mpp }}\right)$ & $64 \mathrm{~W}$ & $64.159 \mathrm{~W}$ & $63.55 \mathrm{~W}$ & 0.247 & 0.708 \\
Voltage at $P_{\text {mpp }}\left(V_{\text {mpp }}\right)$ & $17.5 \mathrm{~V}$ & $17.47 \mathrm{~V}$ & $17.47 \mathrm{~V}$ & 0.171 & 0.171 \\
Current at $P_{\text {mpp }}\left(I_{\text {mpp }}\right)$ & $3.66 \mathrm{~A}$ & $3.67 \mathrm{~A}$ & $3.64 \mathrm{~A}$ & 0.272 & 0.549 \\
Voltage at open circuit $\left(V_{0}\right)$ & $21.3 \mathrm{~V}$ & $21.3 \mathrm{~V}$ & $21.3 \mathrm{~V}$ & 0.00 & 0.00 \\
Current at short circuit $\left(I_{S C}\right)$ & $4 \mathrm{~A}$ & $4 \mathrm{~A}$ & $4 \mathrm{~A}$ & 0.00 & 0.00
\end{tabular}

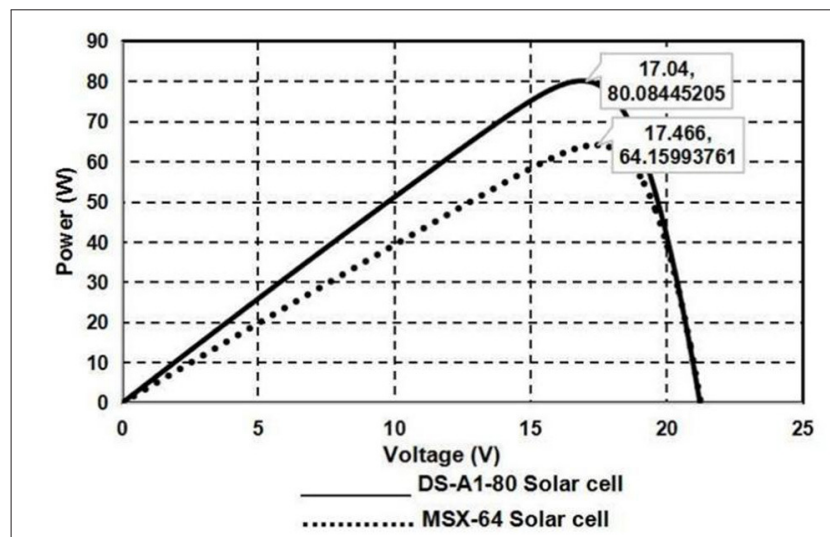

FIGURE 8 | Power (W) vs. voltage (V) curve of proposed two-diode model for DS-A1-80 and MSX-64 at STC $\left(25^{\circ} \mathrm{C}\right.$ and $\left.1,000 \mathrm{KW} / \mathrm{m}^{2}\right)$.

From Equation (12)

$$
\begin{aligned}
& \frac{V_{m p p, S T C}+I_{m p p, S T C} R_{S E}}{R_{S H}}= \\
& I_{L, S T C}-I_{D 1, S T C}-I_{D 2, S T C}-I_{m p p, S T C} \\
& R_{S H}=\frac{V_{m p p, S T C}+I_{m p p, S T C} R_{S E}}{I_{L, S T C}-I_{D 1, S T C}-I_{D 2, S T C}-I_{m p p, S T C}}
\end{aligned}
$$

where $P_{m p p}$ is the peak or maximum power, $V_{m p p, S T C}$ is the voltage at $P_{m p p}$, and $I_{m p p, S T C}$ is the current at $P_{m p p}$, diode saturation currents at the maximum power condition is given by the relation as shown below:

$$
\begin{aligned}
& I_{D 1, S T C}=I_{D s 1, S T C}\left[\left(e^{\frac{V_{m p p, S T C}+I_{m p p, S T C} R_{S E}}{C_{1} V_{T} N_{S E}}}\right)-1\right] \\
& I_{D 2, S T C}=I_{D S 2, S T C}\left[\left(e^{\frac{V_{m p p, S T C}+I_{m p p, S T C} R_{S E}}{C_{2} V_{T} N_{S E}}}\right)-1\right]
\end{aligned}
$$

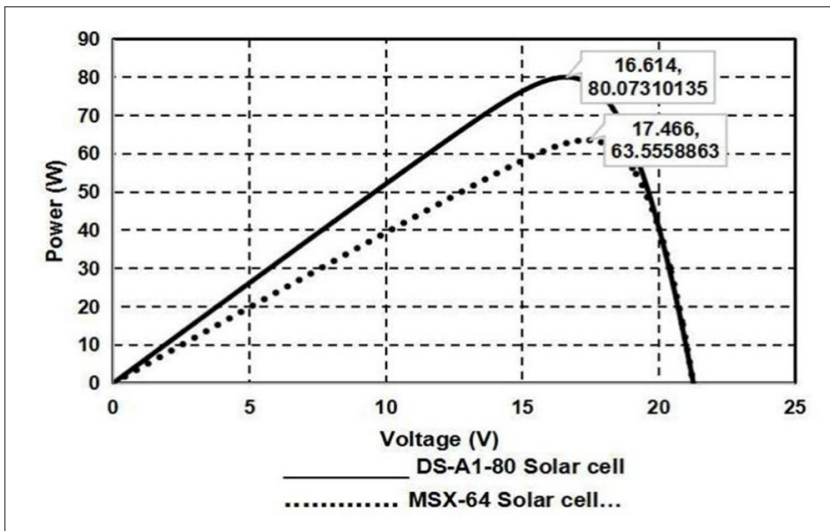

FIGURE 9 | Power (W) vs. voltage $(M)$ curve of one-diode $R_{S H}$ for DS-A1-80 and MSX-64 at STC $\left(25^{\circ} \mathrm{C}\right.$ and $\left.1,000 \mathrm{KW} / \mathrm{m}^{2}\right)$.

\section{Determination of $\mathbf{R}_{\mathrm{SE}}$ and $\mathbf{R}_{\mathbf{S H}}$ Constraints}

Several analytical and numerical approaches $[3,6,7,9,13-$ 15] have been proposed in the literature to evaluate the constraints of one-diode and two-diode models. In this analysis the constraints $R_{S E}$ and $R_{S H}$ are estimated by the same method as described previously [9]. By using effective iteration process the value of $R_{S E}$ and $R_{S H}$ can be estimated with the help of Equation (10). The main takeaway is that the value of $R_{S E}$ and $R_{S H}$ are selected such that calculated power $P_{m p p}$ must be equal to experimental power provided by the constructor data sheet $P_{m p p, S T C}$. This iteration procedure initiates from $R_{S E}=0$ which must vary in directive until it matches the calculated maximum power of $P_{m p p, S T C}$, and simultaneously $R_{S H}$ is calculated. 


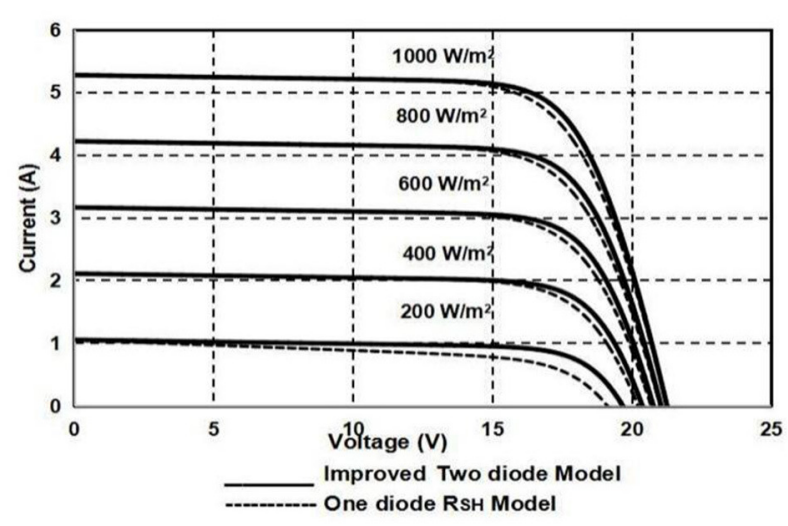

FIGURE 10 | Comparative analysis of current (A) vs. voltage $(V)$ curve for one-diode $R_{S H}$ and proposed two-diode model for DS-A1-80 with different irradiance points at STC $\left(25^{\circ} \mathrm{C}\right)$.

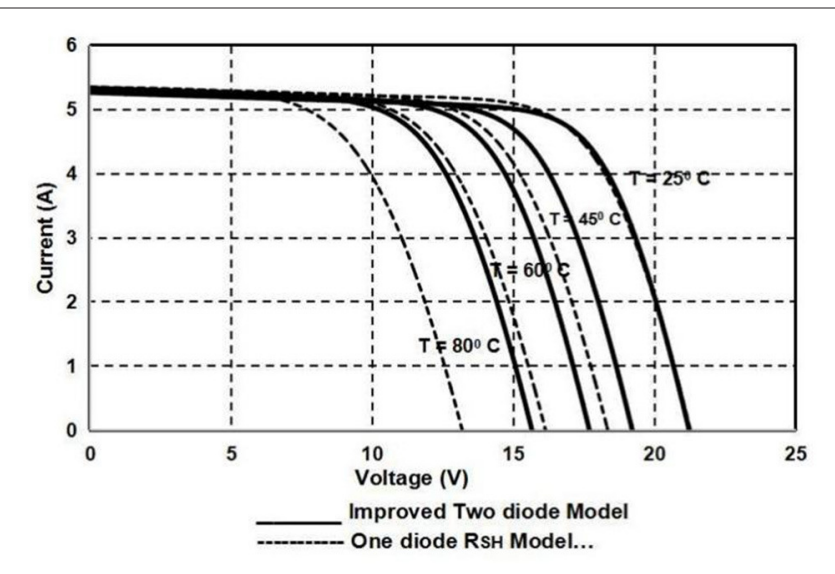

FIGURE 11 | Comparative analysis of current (A) vs. voltage $(\mathrm{V})$ curve for one-diode $R_{S H}$ and proposed two-diode model for DS-A1-80 with different temperature points at STC $\left(1,000 \mathrm{KW} / \mathrm{m}^{2}\right)$.

\section{SIMULATION OF PROPOSED TWO-DIODE MODEL}

The complete sub-system group model of the proposed twodiode photovoltaic (PV) module is represented in Figure 4. By using Equations (2)-(5), detailed simulation models were developed in MATLAB/Simulink. The simulation block diagram of diode saturation current is represented in Figure 5, light current is represented in Figure 6, and module output current is represented in Figure 7. The component specifications of both mono-crystalline and poly-crystalline PV modules are shown in Table 1. Table 2 illustrates the determined values of the proposed two-diode model and Table 3 shows the constraints for the onediode $R_{S H}$ model. Tables 4, 5 summarize the study of relative error of $P_{m p p}, V_{m p p}, I_{m p p}, V_{o}$, and $I_{S C}$ of both mono and polycrystalline solar cells. The proposed two-diode model actually requires only four constraints because saturation current $I_{D S 1}=$ $I_{D S 2}=I_{D S}$ whereas $C_{1}=1, C_{2}$ is chosen $>1.2$ and the value of $p$ is recommended to be a value larger than 2.2 [12].

\section{SIMULATION RESULTS AND DISCUSSION}

The modeling technique characterized in this work is confirmed by measured constraints of certain photovoltaic (PV) cell modules. Two different PV modules; mono-crystalline DS-A1$80^{1}$ and poly-crystalline MSX- $64^{2}$ are employed for verification. We can observe that the calculated values slightly deviate from the manufacturer data sheet value at STC. However, the polycrystalline (MSX-64) cell exactly fits the manufacturer data for the proposed two-diode model. Figures 8, 9 characterize the power vs. voltage curve of $R_{S H}$ and the proposed twodiode model for mono-crystalline and poly-crystalline solar cells at STC. Comparative analysis of the current vs. voltage curve of $R_{S H}$ and the proposed two-diode model for the DSA1-80 solar cell at various temperatures and irradiance levels are represented in Figures 10, 11. Comparative analysis of the current vs. voltage curve of $R_{S H}$ and proposed two-diode model for the MSX-64 solar cell at various temperatures and irradiance levels are represented in Figures 12, 13. From the results we can observe that both models exhibited the same performance at STC. However, the proposed two-diode model showed better performance compared to the $R_{S H}$ model precisely at lesser irradiance levels especially for open circuit voltage. The comparison of estimated values at maximum power $\left(P_{m p p}\right)$ of the two-diode model and one-diode $\left(R_{S H}\right)$ model for monocrystalline (DS-A1-80) and poly-crystalline (MSX-64) solar cells are shown in Tables 4, 5 .

\section{CONCLUSION}

For a quick and consistent photovoltaic module design, an effective, fast, and exact simulator is crucial to examine the performance of the photovoltaic cell under a partial or quick variation of temperature and irradiance. The most prevalent modeling strategy is to apply an equivalent (electrical) circuit that encompasses both non-linear and linear mechanisms. In the proposed work, an improved typical two-diode system aimed at photovoltaic cell modules was developed. Distinct from past photovoltaic modules recommended by many researchers, the developed work only needed the calculation of four constraints. A modest and fast iterative technique was used to estimate $R_{S E}$ and $R_{S H}$ resistances. The accuracy of the developed model was examined by using experimental data provided by the constructors of two different photovoltaic cell modules. Its performable behavior was compared with one-diode $R_{S H}$ models. It was observed that the proposed two-diode model had improved performance specifically at open circuit voltage and short circuit current and maximum power point conditions irrespective of variations in temperature and irradiance. Specifically, it showed better performance and accuracy at lesser irradiance situations. The proposed model was validated for mono-crystalline and poly-crystalline solar cells under standard test conditions.

\footnotetext{
${ }^{1}$ Available online at: http://www.posharp.com/ds-al-80-solar-panel-from-anjidasol-solarenergysciencetechnology_p462201154d.aspx (accessed January 31, 2021).

${ }^{2}$ Available online at: https://www.solarelectricsupply.com/media/custom/upload/ Solarex-MSX64.pdf (accessed January 31, 2021).
} 


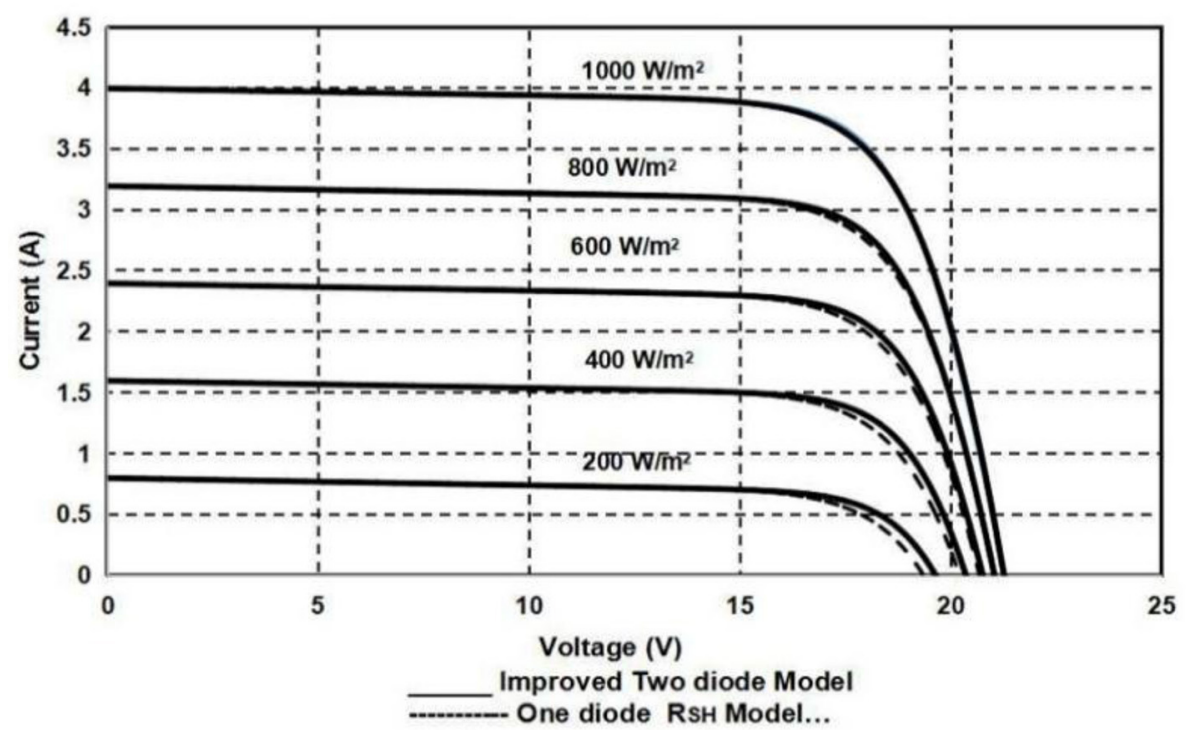

FIGURE 12 | Comparative analysis of current (A) vs. voltage $\left(M\right.$ curve for one-diode $R_{S H}$ and proposed two-diode model for MSX-64 with different irradiance points at $\operatorname{STC}\left(25^{\circ} \mathrm{C}\right)$.

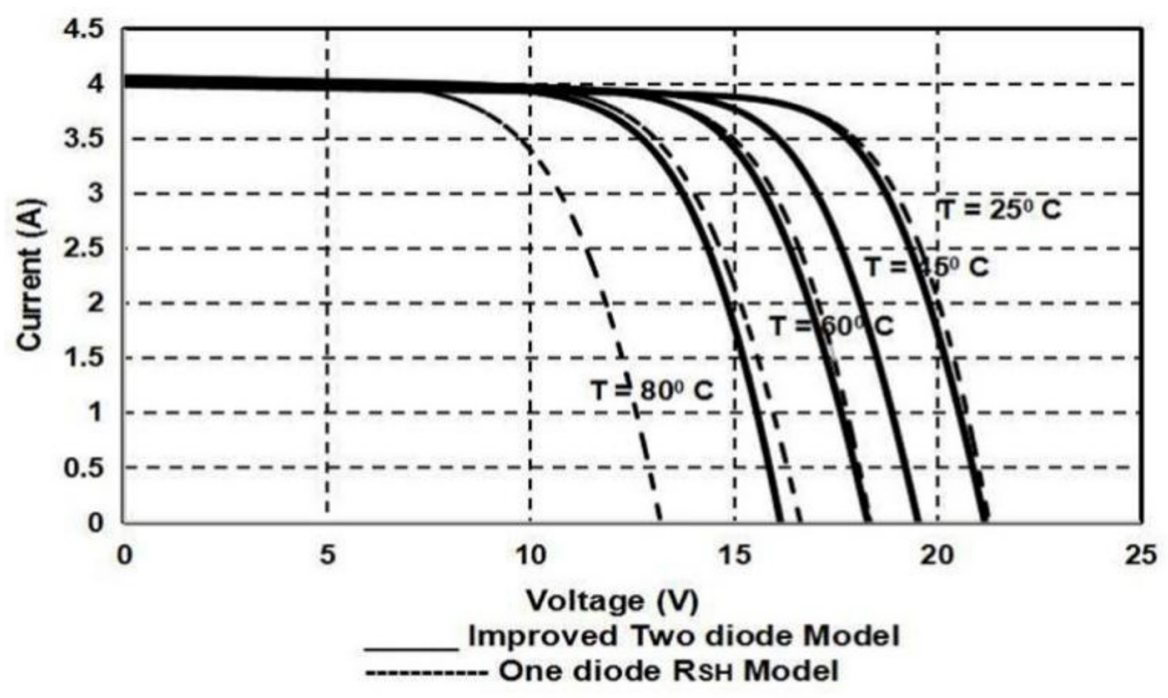

FIGURE 13 | Comparative analysis of current (A) vs. voltage ( $\mathrm{V}$ curve for one-diode $R_{S H}$ and proposed two-diode model for MSX-64 with different temperature points at STC $\left(1,000 \mathrm{KW} / \mathrm{m}^{2}\right)$.

\section{DATA AVAILABILITY STATEMENT}

The original contributions presented in the study are included in the article/supplementary material, further inquiries can be directed to the corresponding author/s.

\section{AUTHOR CONTRIBUTIONS}

All authors listed have made a substantial, direct and intellectual contribution to the work, and approved it for publication. 


\section{REFERENCES}

1. Khanna V, Das BK, Bisht D, Singh PK. A three-diode model for industrial solar cells and estimation of solar cell parameters using PSO algorithm. Renew Energy. (2015) 78:105-13. doi: 10.1016/j.renene.2014. 12.072

2. Shannan NM, Yahaya NZ, Singh B. Single-diode and two-diode model of PV modules: A comparison. In: IEEE International Conference on Gontrol System, Computing and Emerging (Penang). (2013). p. 210-4.

3. Lo Brano V, Orioli A, Ciulla G, Di Gangi A. An improved five-parameter model for photovoltaic modules. Solar Energy Mater Solar Cell. (2010) 94:1358-70. doi: 10.1016/j.solmat.2010.04.003

4. Chenni R, Makhlouf M, Kerbache T, Bouzid A. A Detailed modeling method for photovoltaic cells. Energy. (2007) 32:172430. doi: 10.1016/j.energy.2006.12.006

5. Sera D, Teodorescu R, Rodriguez P. PV panel model based on datasheet values. In: Proceedings of the IEEE International Symposium on Industrial Electronics (ISIE) (Vigo). (2007). p. 2392-6.

6. Singh P, Ravindra NM. Analysis of series and shunt resistance in silicon solar cells using single and double exponential models. Emerg Mater Res. (2011) 1:33-8. doi: 10.1680/emr.11.00008

7. AlRashidi MR, AlHajri MF, El-Naggar KM, Al-Othman AK. A new estimation approach for determining the I-V characteristics of solar cells. Solar Energy. (2011) 85:1543-50. doi: 10.1016/j.solener.2011.04.013

8. Chih-Tang S, Noyce RN, Shockley W. Carrier generation and recombination in $\mathrm{p}-\mathrm{n}$ junctions and $\mathrm{p}-\mathrm{n}$ junction characteristics. Proceedings of IRE, Vol. 90. (1957) 45:1228-43. doi: 10.1109/JRPROC.1957.278528

9. Villalva MG, Gazoli JR, Filho ER. Comprehensive approach to modeling and simulation of photovoltaic arrays. IEEE Transact Power Electron. (2009) 24:1198-208. doi: 10.1109/TPEL.2009.2013862

10. Salam Z, Ishaque K, Taheri H. An improved two-diode photovoltaic (PV) model for PV system. In: International Conference on Power Electronics, Drives and Energy Systems (PEDES) Power India (New Delhi). (2010). p. $1-5$.
11. Mcintosh K, Pietro Altermatt P, Heiser G. Depletion-region recombination in silicon solar cells: when does $\mathrm{m} \_\mathrm{DR}=2$ ? In: Proceeding of the 16th European Photovoltaic Solar Energy Conference (Glasgow). (2000). p. 251-4.

12. Chin VJ, Salam Z, Ishaque K. Cell modelling and model parameters estimation techniques for photovoltaic simulator application: a review. Appl Energy. (2015) 154:500-19. doi: 10.1016/j.apenergy.2015.05.035

13. Alonso-Gracia MC, Ruiz JM, Chenlo F. Experimental study of mismatch and shading effects in I-V characteristics of a PV module. Solar Energy Mater Solar Cells. (2006) 90:329-40. doi: 10.1016/j.solmat.2005.04.022

14. Hejri M, Mokhtari H, Azizian MR, Ghandhari M, Söder L. On the parameter extraction of five parameter double-diode model of photovoltaic cell and modules. IEEE J Photovolt Cells. (2014) 4:915-23. doi: 10.1109/JPHOTOV.2014.2307161

15. Sulyok G, Summhammer J. Extraction of a photovoltaic cell's double-diode model parameters from data sheet values. Energy Sci Eng. (2018) 6:42436. doi: $10.1002 /$ ese 3.216

Conflict of Interest: The authors declare that the research was conducted in the absence of any commercial or financial relationships that could be construed as a potential conflict of interest.

Publisher's Note: All claims expressed in this article are solely those of the authors and do not necessarily represent those of their affiliated organizations, or those of the publisher, the editors and the reviewers. Any product that may be evaluated in this article, or claim that may be made by its manufacturer, is not guaranteed or endorsed by the publisher.

Copyright (C) 2021 Prakash, Singh and Singh. This is an open-access article distributed under the terms of the Creative Commons Attribution License (CC BY). The use, distribution or reproduction in other forums is permitted, provided the original author(s) and the copyright owner(s) are credited and that the original publication in this journal is cited, in accordance with accepted academic practice. No use, distribution or reproduction is permitted which does not comply with these terms. 